\title{
Legally Armenian: Tolerance, Conversion, and Name Change in Turkish Courts
}

\author{
CEREN ÖZGÜL
}

\begin{abstract}
Armenian Studies Program, and Anthropology, University of Michigan, Ann Arbor
\end{abstract}

In 2007, a plaintiff petitioned a civil court in Istanbul. His petition stated that although in the civil registers (kütükte) his name was recorded as Mehmet, he had actually converted to Christianity four months before. Now, he declared, he wanted to take the distinctively Armenian name he had been given at his baptism, Agop, as his new first name. ${ }^{1}$ The lawyer's argument that accompanied the petition was strikingly different from other cases of (everyday) name change heard in the courts of Istanbul and other Turkish cities. Bringing up the historical and political underpinnings of her client's namechange request, she argued: "The village where the plaintiff was born and

\begin{abstract}
Acknowledgments: Research and writing for this study were made possible by grants from the Wenner Gren Foundation, The Council for European Studies at Columbia University, a Society for the Anthropology of Europe Pre-Dissertation Award, an Andrew Silk Dissertation AwardCUNY, the National Science Foundation, and the Mellon/American Council of Learned Societies Dissertation Completion Fellowship. My thanks go to the Association of Political and Legal Anthropology (APLA) for awarding an early version of this article the Best Graduate Student Paper Prize in 2010. Another earlier version was presented at the workshop "The Politics of Conversion: Historical Perspectives, Sociological and Anthropological Insights," at the Middle East and Middle Eastern American Center, CUNY-Graduate Center, in December 2010. I have benefited from the detailed and thoughtful reviews and criticisms of Jonathan Boyarin, the workshop discussant, and Beth Baron, with whom I co-organized the workshop. The essay has benefited from the good fortune of intellectual engagement with Raja Abillama, Talal Asad, Anny Bakalian, Vincent Crapanzano, Adrienne Lotson, Shea McManus, Nada Moumtaz, Ted Sammons, and Jane Schneider. I am especially grateful for the intellectual generosity and critical engagement of Arman Artuç, Ayşe Parla, Banu Karaca, Esra Özyürek, and Kabir Tambar, who read and patiently commented on various drafts. I would especially like to thank my family, all of them lawyers: my sister Gökçesu Özgül provided invaluable research assistance; my parents Niyazi and Güven Özgül taught me how to read the heavy jargon of laws and court decisions in Turkey. I am immensely indebted to CSSH Editor Andrew Shryock for his invaluable recommendations and encouragement toward this essay's publication. I thank David Akin for his wonderful editorial feedback. Finally, I owe a debt to the lawyers, registrars officers, and return converts in Turkey who participated in my research but who must remain anonymous.

${ }^{1}$ I use plaintiffs' real names only when their stories were published in newspapers; all others are pseudonyms.
\end{abstract}


grew up was originally an Armenian village located in the Eastern Anatolia that converted to Islam. However, the Armenians living there never lost their Armenian Christian identities. Recently, the plaintiff converted from Islam to Christianity to go back to his own religion, and ... registered his religion as Christian with the state's authorities."2

The court ultimately rejected Agop's request, but his petition was only one of many like it. Since the early 1990s, hundreds of officially Muslim Turkish citizens claiming Armenian descent have submitted petitions to Turkey's legal authorities for changes of their name and religion in the public record. ${ }^{3}$ These persons trace their ancestry to Christian Ottoman Armenians who adopted Islam in the context of massacres culminating in the genocide of 1915.

Perhaps the most significant aspect of legal reform in Turkey in the wake of the European Union's accession efforts is the new law that makes it possible for citizens of Turkey to change, as they see fit, their religious affiliation on their national identity cards. This marks a shift from previous practice, in which such a change required the approval of a local court (Demiralp 2003: 273; see also Hiz and Y1lmaz 2004). ${ }^{4}$ Although the column noting a person's religion still exists on Turkish identity cards, which are the primary form of identification required of all citizens, the content of the religion column can now, under the new regulation, be decided by the bearer. A wave of namechange cases has followed this reform, since personal names indicate ethnic and religious affiliation in Turkey. ${ }^{5}$ Many observers have remarked on the coincidence in timing between these reforms and the December 1999 declaration of Turkey's candidacy for membership in the European Union, asserting that the move represents an effort to realize this membership possibility

2 Beyoğlu Civil Court (3. Asliye Hukuk Mahkemesi), Esas No. 2007/106, Karar No. 2007/197. All translations are mine except where noted.

3 There are no official statistics concerning name or religion change cases in Turkey. I was given this information by a population registrar. Archbishop Aram Ateşyan stated that every year between sixty and seventy Islamized Armenians return to their ancestors' religion (Ateşyan 2012). As to their timing, Ateşyan emphasized the "democratization" of Turkey as the reason for reconversions now (Konuralp 2010). However, plaintiffs had a variety of reasons, ranging from the influence of the Kurdish struggle on their realizing the importance of minority differences, to the effects of their past political activism. For a detailed discussion of reasons behind decisions to reconvert, see Özgül 2013.

4 The religious affiliation of every citizen in Turkey is recorded by legal authorities and registered on national identity cards at birth. Before the legal reform, Turkish law required individuals who wanted to change their religious affiliations in the official records to first obtain a "document of conversion [ihtida belgesi] from the highest religious authority of the religion/sect in Turkey to which they wish to convert. With this crucial document in hand, the next step was to petition a local court and ask for a change in the official records. If the local court accepted the request, the plaintiff would proceed to the local registrar's office with a document indicating the court's decision and apply for a change in the column on their identification cards designating religious affiliation.

5 Non-Muslim confessions in Turkey include recognized minorities: Greek Orthodox, Armenian Apostolic, and Jewish, as well as unrecognized minorities of different ancient Christian sects, including Assyrians and Nestorians. 
(Kirişci 2009; Trenz 2007). Because the reforms were a critical moment of recognition for confessions other than Islam, they received praise from the broad coalition that connects the governing Justice and Development Party (AKP) to a diverse array of political activists, NGOs, committees of legal scholars, and, of course, the European Union. Most commentators claim that by recognizing religious and ethnic difference among its citizenry, Turkey is becoming a more robust democracy as it "adopts and introduces policies that become more and more inclusive towards minorities excluded from given and established definitions of national identity" (Kirişci 2009: 1$)^{6}$

This legal development is widely considered a gateway that, for the first time in the history of the Turkish Republic, will lead to confessional pluralism and religious tolerance. In what follows I argue to the contrary-I contend that it is wrong to assume that democracy and democratization are simply matters of acknowledging religious and ethnic diversity among the national population, based on supposedly recognizable and standard features of minorities. Neither supporters nor critics of the recent legal reforms have questioned how the law differentiates minorities through its definitions of religion, ethnicity, and language (Mahmood 2012; Povinelli 2002). I suggest that religious tolerance is not merely a product of public, legal assertions that recognize religion as constituting minority difference. Rather, as I demonstrate, legal reform has shifted the definition of religion in legal space. To foreshadow the argument, I contend that analyses of the recent reform process have implicitly redefined religion as culture, and religious freedom as an individual right to belief. What Wendy Brown calls "tolerance talk" (2006: 2) - tolerating minority differences (including religion) as culture-is central to how the recent legal reforms are presented as a means to "enhance" religious freedom. I will show that, even in those cases where name-change petitions are granted, the courts simply establish the legal subjectivity of the converts as Christians and fall short of establishing their status as Armenians.

As I discuss the legal regulation of name changes, I will also try to illuminate critical shifts in the debate over what secularity means in Turkey. Through an analysis of definitions of religion before and after the reforms, I will pose a critique of multiple readings of secularism. The article is divided into three parts. In the first, I discuss a court case from my own research on a convert population in Turkey, the descendants of forcibly Islamized Armenians. I draw on eighteen months of ethnographic study among this group, including interviews with lawyers, plaintiffs, government officials, and judges, as well as close readings of court arguments and judges' written decisions. I concentrate

\footnotetext{
${ }^{6}$ The most common examples given of improvements in the condition of minorities were the restoration of ancient Armenian churches, the abolishment of the minority bureau that exercised state surveillance over non-Muslims, and the restitution of minority vakif (foundation) properties. See U.S. Bureau of Democracy, Human Rights, and Labor 2011.
} 
on the specific legal arguments that Armenian converts and their lawyers put forward in the secular courts in contemporary Turkey, and how state legal officers respond to them. In the second part, I analyze the historical foundations of the regulation of religion and name change by engaging more fully and explicitly with law as a site where minority difference is constructed, authorized, and challenged. My purpose is to show the relationship between individual names and religious denomination, and how these are regulated by the same legal principles in Turkish courts. The article's last part interrogates the idealization of religious tolerance and offers an alternative reading of how it functions in the larger regime of secularism in Turkey. I conclude by pointing to the differences between Wendy Brown's framework of liberal secular states and the situation found in Turkey.

\section{ELEPHANTS IN THE COURTROOM: CLAIMING ARMENIAN-NESS IN TURKISH COURTS}

The religion column on Turkish identity cards has been a central issue in legal reform. ${ }^{7}$ Following the European Union's suggestion, ${ }^{8}$ the new Population Services Law was adopted in 2006 and made the indication of religion on the cards optional. Moreover, a court order was no longer required to change one's religious confession. The new law provides that, "Requests about the religious information in household registers shall be approved, modified, left blank or deleted in accordance with the written application of the concerned person." Registering religious conversion in official records also ceased to fall under the jurisdiction of the First Degree Appeal Courts. The legal aspect of religious conversion is now marked by a lack of regulation, ${ }^{10}$ and citizens of Turkey, for the first time, have the right to assume the religion of their choosing on their identity cards. ${ }^{11}$ Yet several questions remain unanswered: How is religion

\footnotetext{
7 Identity cards in Turkey were part of bigger debates in the European Union. Greece was the only EU country in which indicating religion on identity cards was compulsory. In 2000, the Greek government deleted religious faith information from identity documents to harmonize its domestic legislation with European standards (Molokotos-Liederman 2007). National identity cards have been the subject of discussion and criticism worldwide. For a discussion of how registration of religion in national identity cards fortifies religious boundaries in Indonesia, see Connolly 2009.

8 The Commission prepared three reports about Turkey up to the time of the adoption of the new Law in 2006 (see European Commission against Racism and Intolerance [ECRI] 1999; 2001; 2005). All three noted that the elimination of the religious record from identity documents would improve freedom of religion in Turkey. For the texts, see: http://www.coe.int/t/dghl/monitoring/ecri/Country-by-country/Turkey/Turkey_CBC_en.asp.

9 Article 35 of The Population Services Law of 2006.

${ }^{10}$ Here, I want to briefly note that Turkish legal reform goes against the grain of the strict bureaucratic regulations concerning religious conversion found in other countries where similar constructions of citizenship on ethnic and/or religious bases exist. A case in point is Israel, where conversion emerged as a way to demand citizenship (Kravel-Tovi 2012; Seeman 2009) or contributed to biologically constructed racial discourses of belonging (Abu El-Haj 2012).

${ }^{11} \mathrm{I}$ do not argue that religious conversion is secure and sanctioned by the state after legal reforms. While there is a display of legal tolerance in the courts, Özyürek (2009a) shows that
} 
defined in the legal reform? Do citizens registered as Christians become minorities with the cultural, linguistic, and ethnic rights of other recognized minorities in Turkey? In short, what are the legal and material consequences of the freedom to select your religion on your identity card? ${ }^{12}$

Answers to these questions lie in name-change cases like the one featured at the beginning of this essay. Moreover, these cases show the importance of ethnic belonging and historical context to understanding how the recent legal reforms actually work. After petitioning the state to record the change in an individual's religious affiliation, name change remains a legal procedure in which converts must solicit the state's approval. Mehmet, the plaintiff in my opening example, changed his religion from Islam to Christianity by submitting a petition to the civil officials. ${ }^{13}$ His request was accomplished without difficulties, according to his lawyer, Mari Hanım. However, as Mari Hanım also emphasized, this change of religion did not "make" him an Armenian, ${ }^{14}$ which was the real intent of his conversion.

The person known as both Mehmet and Agop in his village belongs to a group of people who claim to be descendants of forcibly Islamized Armenians. ${ }^{15}$ The initial conversion of his grandparents is the implicit context of the court's rejection of his name-change request (Deringil 2012). The rejection,

conversion is understood to threaten the state's security. This perception even incited a series of attacks against protestant converts, priests, and missionaries (Özyürek 2009b).

${ }^{12}$ For excellent discussions of the limitations of rights discourse and universal citizenship in the case of marginalized groups, see Brown 1995; and Parla 2011.

${ }^{13}$ Conversion to Armenian-ness starts with the change of religion in the official records of the state, but a following necessary step is baptism in the Armenian Church. It is this last step that eventually makes possible the use of rights granted to the rest of the Armenian community in Turkey. As the applicant requires the permission of the Armenian Patriarchate for baptism, this process involves another hurdle for return converts. The Patriarchate is usually unsympathetic to their claims of Armenian-ness, albeit for reasons different from those of the Turkish courts. I take up these issues in more detailed work currently in progress. For more information on the background of these conversions, see Özgül 2013.

${ }^{14}$ Being Armenian means to hold a minority identity in Turkey, one that is recognized as religious as well as linguistic difference. These two characteristics are most visible in distinctive Armenian names. For another name change case that draws attention to the difference between Armenian names and Armenian ethnic identity, see Resmen 'Ermeni' 2008.

${ }^{15}$ This label is one of many commonly used to refer to this community. Others are "hidden Armenians," "Muslim Armenians," "crypto-" and "Dönme Armenians." However, all of these terms have significant limitations. My informants expressed resentment at many of these descriptions, especially the "crypto" designation because it masks hatred of individuals with Armenian roots who lived as Muslims. The term "hidden Armenians," according to their accounts, is also highly problematic since it suggests that they are cowards or traitors who have, in their own terms, "something to hide." "Muslim Armenians" looks less problematic, but it carries the danger of normalizing their precarious position vis-à-vis both the Turkish Muslim majority and the Armenian minority. They are accepted as neither "Armenians" nor "Muslims." I use "descendants of forcibly Islamized Armenians" because I believe it emphases their grandparents' initial conversion to Islam as a forced event. For a detailed discussion of these terminological problems, see Özgül, 2013. 
in other words, is closely tied to the deeper historical-political context of the recent wave of conversions. Regarding historical violence against Armenians in the last decades of the Ottoman Empire, Turkish governments, including most recently the AKP, ${ }^{16}$ have consistently rejected accusations of genocide, characterizing the events (and the resulting deaths of thousands) as "widespread partisan fighting" in which both Turks and Armenians were killed, and "deportations" necessitated by wartime security concerns (see Akçam 2004; Göçek and Suny 2011). ${ }^{17}$ The debates over naming the violence perpetrated against Armenians continue to shape policies that affect the descendants of Ottoman Armenians today (Akçam 2004; Dadrian 1995). Given that the Turkish state refuses to recognize the genocide, the return conversion of descendants of forcibly Islamized Armenians unmasks a violence that is still largely unmentionable (Altınay and Çetin 2009; Altınay and Türkyılmaz 2011; Deringil 2000; 2012; Özuzun 2006; Üngör 2011).

Although they could theoretically convert to Christianity and keep their "Muslim" (i.e., ethnic Turkish) names, the insistence of Armenian return converts on the double change of religion and name points to the fact that a nonMuslim, non-Turkish name is a marker of minority identity. When I asked a lawyer who represents (de-)converting Armenians why it is so important for them to adopt Armenian names, he answered, "A Muslim name conveys the assumption that the person who carries it is a Muslim." Therefore, he continued, the main aim in such name-change cases is to "introduce the convert to the public as an Armenian."18

Indeed, in my interview with Mehmet/Agop's lawyer, Mari Hanim, she immediately mentioned the judge's attitude and the "pact" linking the judge, the public prosecutor, and the population registrar in opposition to the claims of her client, as well as against those who acted as witnesses to his being Armenian. She talked at length about an incident that occurred when two witnesses testified in court that they had known the applicant by the name Agop since his conversion, as he had stated in his petition. They said they had in fact known him by this name since childhood, and added, "We used this name when playing football back in our childhood village." The judge, not knowing

\footnotetext{
16 Turkey's Leader 2011.

17 Until recently, statements or publications explicitly or implicitly identifying 1915 as a period of genocide against Armenians were prosecuted under Article 301 of the Turkish penal code. The law does not explicitly prohibit the acknowledgement thereof, but public prosecutors interpret such acknowledgements as "insulting Turkish identity" (see Karaca 2011). Although it was amended in 2008 in the face of European Union accession reforms, as well as domestic pressure (see Algan 2008), the revised iteration is still used to prosecute any acknowledgement of the genocide as insulting Turkish-ness. Another infamous article of the Turkish criminal code, Article 312, is also used to prosecute any mention of the words "genocide" or "death" of the non-Muslim and/or non-Turkish subjects of the Ottoman Empire as "incitement to hostility and hatred based on racial and ethnic origin.” See U.S. Bureau of Democracy, Human Rights, and Labor 2001.

18 A sequel to this article will discuss my method of collecting legal material in Turkey.
} 
what to say in the face of this undeniable evidence of the existence of a village full of Turkish citizens officially registered as Muslims but claiming Armenianness, tried to intimidate the witnesses by raising his voice and ridiculing their testimony: "Oh, you are from the same village, so all of you are Armenians?!" Nonplussed by the judge's response, the witnesses tried to explain the ethnic composition of their village, only to draw more of the judge's ire. He declared that the court was not the place for "football playing stories" and passed his judgment without further comment on the entirely plausible testimony. ${ }^{19}$ The tide had shifted. As the plaintiff's lawyer continued to press her case, the public prosecutor and the population registrar began to laugh and derisively repeat fragments of the witnesses' statements. According to the decision on record, the judge followed procedure and asked for the opinions of the two state officials, and they both stated that four to five months was not enough time for the plaintiff to familiarize himself with his new religion, and therefore that his petition for a name change should be denied.

Mari Hanim, trying to challenge the court's interpretation of Agop's relationship to his new belief, as indicated by the word "familiarize," argued again that her client had not simply converted to Christianity but had converted back to Christianity, intending to rejoin his ancestors' community and religion. Thus, she reasoned, his case should not be considered in terms of converting to a new religion but as a return to his original religion lost during state violence against Armenians. By defining religion as an element of ethnic (Armenian) belonging, and by pointing explicitly to its basis in a communal history that has unfolded in a village in Turkey, Mari Hanim was arguing against the clearcut boundaries between religious and ethnic identification, between Muslim and non-Muslim, and between Turk and non-Turk, upon which the state's registrars had based their argument.

The court decided against the plaintiff and rejected his petition for a name change on the basis of his failure to provide a just cause. Because the plaintiff missed the deadline for filing an appeal, his case never reached the Court of Cassation (Yargitay). "I am sad I couldn't take it to the upper court," Mari Hanim told me, "yet I don't think that it would make a difference. The ridicule is usually the same there." Her comments indicate a certain anxiety about how

19 For a comparison with the struggles for recognition as Native American "tribes" or "nations" in the United States, see Clifford 1988. Clifford describes a similar process during the 1976 Mashpee trial in Massachusetts, in which plaintiffs and defendants constructed competing representations of Mashpee history, culture, and tribal identity. For another critical perspective on "producing legal truths," see Coutin 1995.

20 In Turkey there are two Courts of Cassation (Danıştay and Yargıtay), the courts of appeals that review decisions of the lower courts if a party decides to appeal their decision. A Court of Cassation can annul or accede to the lower court's decision. In cases of annulment, the case is remanded to the lower court. For the related decisions on freedom of religion in Danıştay, see Karahanoḡulları 2010. More information about the structure of the Turkish court system can be found at: http://www.yargitay.gov.tr/eng/index.php; and http://www.danistay.gov.tr/eng/index.html. 
she and her client would be treated in the Court of Cassation. They would still be arguing for an alternative definition of religion, and recognition of a violent historical episode, by insisting that Agop's conversion and subsequent name change represented a return to Armenian ethnicity.

In the critical literature on secularism in Turkey (Akan 2011; Navaro-Yashin 2002; Özyürek 2006; Parla and Davison 2008; Tambar 2010), two studies in particular use religious conversion to scrutinize the relationship between ethnicity and religion. ${ }^{21}$ Marc Baer $(2004 ; 2009)$ analyzes the historical struggle of the Dönme ${ }^{22}$ for equal citizenship in the new Republic, where they arrived after the great population exchange between Greece and Turkey in 1924. Through the Dönme's failed efforts to join as equal citizensthey were widely rejected as crypto-Jews who could not, therefore, be true Muslims or Turks - Baer shows how Turkish secularism connected religion to race in order to utilize both as salient features of belonging despite official claims that Turkish citizenship designated a purely civic relation. Esra Özyürek discusses recent Turkish conversions to Protestantism in order to shed light on perceptions of religion in the wider context of Turkish sovereignty (2009a) and nationalism (2009b). She analyzes secularism as a strategy to create a homogeneous, united, and loyal body of citizens, and she argues that secular nationalists perceive conversion as a threat to national unity (ibid.: 400). ${ }^{23}$ Against the grain of arguments that emphasize Turkish secularism's tolerance towards minority religions, both of these works demonstrate how Turkish secularism's nationalist and racist character is particularly visible in its exclusion of convert populations.

Descendants of the forcibly Islamized Armenians, in their attempts to convert to Armenianness, render even more visible the entanglements of religion and ethnicity in Turkey, even if the numbers of such reconverts are small. What makes them so central to the discussion of Turkish secularism is that, as was evident in the discussion of Mehmet/Agop's court case, they challenge the seemingly natural definition of religion in the legal reform as a personal belief that is registered and can be easily changed on identification cards.

As the idea that every individual should be categorized and labeled has increasingly shaped the terms of citizenship, civil registers and identification papers have assumed a prominent place in peoples' relationships to state institutions. Changes in the instruments of classification alter the types of identities

\footnotetext{
21 Also see Akan (2011) for a discussion of how studies of Turkish secularism have "factored out" non-Sunni and non-Muslim minorities and considered them a separate field. He powerfully argues that this separation contributes to reducing the debate on Turkish secularism "to the dichotomy of Kemalist versus Islamists" (ibid. 196).

22 "The Dönme" are the descendants of Jewish followers of Shabbatai Tzevi, who converted to Islam (Baer 2004: 682).

${ }^{23}$ For a similar discussion of the exclusion of minority religious confessions from the national body, see Pandey 1999.
} 
that it is legally possible for individuals to assume and still claim citizenship (Noiriel 2001). In one sense, these shifts have included potentially empowering aspects, based on the increased recognition of minority groups (Gordillo 2006; Longman 2001; Taylor 1994; Yngvesson and Coutin 2006). However, like property titles, censuses, surveys, and other forms that have been carried over from previous eras, identity documentation today also constitutes and consolidates the state's authority. As the state extends its taxonomy of acceptable names and recognizable religious affiliations, it affords individuals more latitude for official self-representation, yet the process simultaneously creates more visible and hence more manageable subjects, and it facilitates discrimination against religious minorities by marking them. Either way, identification cards and civil registers provide a salient illustration of the ongoing tension between recognition and regulation. The redefinition of religion in the namechange cases of Armenian converts links religion to ethnicity and subsequently to historical episodes of ethnic violence. Return converts not only represent pollution of the desired homogeneity of the national body, they also force the courts to come to terms with the 1915 genocide, which is the most taboo topic in the history of the Turkish Republic (Akçam 2004; Bloxham and Göçek 2008).

Officially, the AKP introduced the legal reform as a move toward religious tolerance and to remedy social ills born of what is colloquially known as Kemalist secularism. Allegedly, it granted the long-overdue cultural and political recognition of ethnic and religious minorities (Taşpınar 2007; Yavuz 2003; White 2013). The critics of Kemalist laicism supported legal reform as doing away with this particular illiberal, republican mode of secularism, which excluded religion from the public sphere while also granting Islam a monopoly on what is defined as legitimate religion. The recent turn in secular politics is explained as the emergence of a liberal and tolerant model of secularism with an ideology of individual freedom of belief (Kuru 2009). The debate between Kemalist secularism and the AKP, in this view, was "not simply a conflict between secularism and Islamism, but rather a discussion about the true meaning and practice of secularism itself" (ibid.: 164). ${ }^{24}$

Scholars of Turkey are not alone in differentiating modes of secularism. A range of analysts has argued that secularism is not a single ideal model, or simply an invention of European culture and Christendom imposed on Muslim societies (Taylor 1998; McClay 2001). This line of scholarship on Turkey differentiates between the republican model and the liberal-tolerant model, arguing that not all modes confine religion to the private sphere. Yet

\footnotetext{
24 Kuru (2009) discusses two modes of secularism: "Anglo-American passive secularism" that accepts religion's role in the public sphere, and "French assertive secularism," (or laicité), which is hostile to the manifestation of religious symbols in the public sphere and in state institutions. He marks the shift in Turkish secularism as one from Kemalist assertive secularism to the passive secularism of the AKP.
} 
the distinction between the private and public spheres remains intact, as do "the secular" and "the religious" as analytical categories. More importantly, the continuities between the Kemalist model and the AKP's treatment and governance of minority religious difference have been ignored. Instead of coming to an easy conclusion as to what secularism is, or how many modes exist, critical scholars of secularism have powerfully shown that the blurring of public and private, and of the religious and the political, is not exceptional but rather is endemic to secular politics (Agrama 2010; Asad 2006; Connolly 1999; Fernando 2010; Sullivan 2005). This article will show how these supposedly different modes of secularism in Turkey both work on the same principleboth reserve the power to define religion.

Before I turn to other court cases that deal with name changes sought following changes in religion, the next section briefly reviews the history in Turkey of the legal regulation of names, of name change, and of religious homogenization in order to begin highlighting the role of law in defining the central categories of secularism.

A BRIEF HISTORY OF RELIGION, ETHNICITY, AND NAMES IN TURKISH L A W

In the most critical move of the global spread of secularization, the definition of religion changed from a matter of communal belonging to the individual right to belief (see Asad 2003; van der Veer 2001). ${ }^{25}$ Turkey, where the religious affiliation of every citizen was recorded by legal authorities and registered on national identification cards at birth, was not exempt (Aybay 2004).

Turkish civil law, too, constructs naming as an essentially individual right that is an inalienable part of a citizen's legal person. This attachment of the name to the individual also worked to mark it as an indicator of the individual's religion. Several decisions of the Court of Cassation attest to the notion of the individuality of the name. One 1992 ruling stated that a name is "... a word that defines people and distinguishes them from others. Since everyone has a personality and an 'essence' (özvarlik) of their own, it is their right to demand that their personality should be distinguished from others.' Therefore, the right to have a name is, in its essence (nitelik bakimindan), a personal right just like a person's honor and life." ${ }^{26}$ In this sense, personal names play a curious role in Turkey. A name is, legally, both the most personal item that belongs to an individual and public knowledge about a citizen's identity. ${ }^{27}$

${ }^{25}$ For a discussion of the legal aspects of freedom of religion in the pre-reform era, see Esen and Gönenç 2008. For state control over Sunni Islam by the establishment of the Diyanet, the Directorate for Religious Affairs, and the repression of other Muslim sects, see Gözaydın 2009.

${ }^{26}$ Decision of the 18th Chamber of the Court of Cassation, 1992/411 E., 1992/1351 K.

27 The public character of personal names is perhaps most evident in the stipulation concerning name-change cases. According to related law, name change should be accompanied by a declaration of both the previous and the adopted names of an individual in a daily newspaper (Demiralp 2003: 158). 
It exists in the space where public and private - a distinction crucial to secular power-overlap and become indistinguishable. This fact marks personal names as crucial for the state and its judiciary to keep under control. As I will illustrate presently, there are many requirements for name-change cases in Turkey that index a statement about the limits on the requests individual citizens can make to the state.

The personalization of religion and the significance of personal names as indicators of the individual's confession were perhaps reflected most clearly in the format and official role of personal identification documents (Aybay 2004). In Turkey, personal identification cards, in particular, reflected the complexity of constraints enforced by the state pre-legal reform in that they formalized religious confession and individual names, and they required judicial review before any changes could be made (see note 5).

Unlike the column indicating religion, in the Turkish legal imaginary a change of name is a basic, regular act through which an individual may take a state-sanctioned opportunity to adopt a name other than that registered at their birth. Falling under the mundane category of "corrections of the records" (kayıt düzeltme), the Turkish Civil Procedure Law's protocol for name-change applicants appears simple at first sight. Government population registrars explained to me in interviews that the most common cases involve citizens who apply to officially adopt middle names that their families did not register on their identity cards when they were born. Left completely out of the picture is any demand that goes beyond this, such as to make changes due to a change of religion, or to adopt a minority name.

Turkish civil law also constructs naming as an individual right that is an inalienable part of a citizen's legal person (Demiralp 2003: 4). Any person eighteen years or older can adopt any name provided that he or she can demonstrate a "just cause" (Ekşi 2008: 33). To establish a just cause, an applicant must demonstrate, with support from at least two witnesses, that for a considerable amount of time prior to the court proceedings they have already been known in public by the name they want to assume. The plaintiff may support this claim by providing evidence, such as phone bills, under the demanded name, but in addition they must avow an intention to take on that name permanently. The name cannot be offensive, such as one that contains racial slurs. The law also stipulates that children cannot receive names that do not conform to national culture, moral norms, customs, and traditions.

Furthermore, that name-change petitions are single-party cases (nisbi neshep) categorizes them in Turkish Civil Procedure Law as cases "without a dispute," having "no opposing two parties, or a dispute, a disagreement between them." 28 However, the population registrar (nüfus memuru) and the

${ }^{28}$ Medeni Kanun [Civil Code], Article 27. 
public prosecutor (cumhuriyet savcisi) must be present in court, where they are required to offer the presiding judge an evaluation of the plaintiff's case (Demiralp 2003: 167). While name-change hearings are officially single-party cases, state agents are present and act as de facto opponents.

The significance of the presence of state officials as the opponent party becomes even clearer when we examine the conditions that constitute a "just cause" for a name change. Here sole authority lies with the judge to rule based on the plaintiff's petition, statements (mütalaa) by the population registrar and the public prosecutor, and the precedence (ijtihat) of higher courts. ${ }^{29} \mathrm{~A}$ legal scholar summarized the bottom line of all these regulations: "The individual does not have the right to adopt any name they like" (Ekşi 2008: 67).

In addition to the legal regulations of name changes, laws enacted to secure ethnolinguistic nationalism also impose a strict control over personal names, and have turned naming into a realm of struggles for minority recognition (Bayır 2013; Kılınç 2010; Kurban 2003). The Language Reform of 1928 established the Latinized Turkish alphabet and criminalized the use of any language other than Turkish (Ölmez 2000; Sevinçli 2006). As a necessary feature of "Turkification," the state imposed linguistic uniformity upon a population whose given names as well as surnames were previously drawn from a multitude of languages and traditions. Under this reform, outliers were forbidden (Türköz 2007; Scassa 1996). Following the Language Reform, prosecutors regularly opened court cases against public use of the letters q, w, and x, which do not exist in the Turkish alphabet but do in Kurdish (Aslan 2009; Ekşi 2008; Esen and Gönenç 2008). ${ }^{30}$

The Surname Law of 1934 required every citizen to adopt a family name and enforced certain restrictions on the types of surnames they could adopt. These restrictions indicate the state's motives were more than purely administrative. Article 3, for example, forbade to "tribes and foreign races and ethnicities" any names related to military rank and civil officialdom, surnames deemed unsuitable to "national customs," and names that could be perceived as "disgusting" or open to ridicule. Surnames also had to be Turkish words. ${ }^{31}$

29 By "High Court," I mean the Court of Cassation (Yargitay), Turkey's highest civil and criminal appellate court. A separate high court exists for administrative law: the Council of State (Danıstay). There is also a Constitutional Court (Anayasa Mahkemesi). In Turkey, the Court of Cassation is the court of appeals of last resort; it reviews lower court decisions to ensure standardization in legal practice. If the Court of Cassation does not agree with a decision, it annuls it and remands the case to the lower court. If the lower court insists on its previous decision, the General Assembly of the Court of Cassation concludes appellate review of the lower court's judgment and makes a final decision on the case. More information about the Turkish Court of Cassation can be found at www.yargitay.gov.tr.

30 This is mainly to forbid Kurdish names. See Case of Ünal vs. Turkey, Judgment of 16 November 2004.

31 The Article, which stipulated that children could not be given names contradicting the "national culture" and "Turkish customs and traditions," was changed in 2006 during legal reforms. The amendment dropped the terms "national culture" and "Turkish customs and 
The only exception to these two regulations on names concerned the minorities "recognized" under the 1923 Lausanne Treaty. Persons in this category were allowed to take non-Muslim/non-Turkish names, but only if transliterated to accord with the Turkish alphabet. This right was not protected by law, however - the law allowed recognized "minorities" to adopt their "religious and cultural" names simply by not explicitly forbidding them to do so. ${ }^{32}$

The Treaty of Lausanne ${ }^{33}$ extended international recognition to the Turkish Republic. It established the legal status of minorities in Turkey, since in return for European recognition the new state granted "non-Muslim communities" special self-governance rights based on their religious differences. Yet because the treaty did not specify which communities would benefit from this legal recognition, the new Turkish state granted it selectively. While Jewish, Armenian, and Greek communities within the empire were recognized as religious minorities, official minority status was denied to Christian populations native to Anatolia (such as Assyrians) and to the relatively new Christian communities such as recent converts to Protestantism (Özyürek 2009a). Also left out were Kurds and non-Sunni Muslim sects such as the Alevis. Together, these "unrecognized" groups became the main targets of homogenization efforts under the discourses of "equal citizenship" (Yeğen 2004). Following the terms put forth in the treaty, a notation of "Islam" as a person's religion of record came to connote Turkishness, and having made Muslim synonymous with Turkish, the registers denied ethnic and sectarian differences within the Muslim majority. ${ }^{34}$

Despite this international recognition, in the new Turkish Republic the legal status of the "recognized" minorities was unclear and far from stable (Cagaptay 2006). Through the treaty, while religion emerged as the main marker of difference, specific terms of distinction such as ethnicity and specific religious affiliation were subsumed under the catchall category of "NonMuslim. ${ }^{, 35}$ Because the emerging definition of religion in the new nation-state

traditions" and prescribed only that names that disregarded moral norms or offended the public could not be given as first names.

32 Demiralp (2003: 177-78) quotes a circular of the Ministry of the Interior, General Directorate of Civil Registration and Nationality, dated 29 November 1985, which states, "There is no objection [in the law] to the names given to our Christian citizens that are in accordance with their religion and culture; in fact it is in accordance with the stipulations of the Lausanne Treaty, [and] legislations do not prohibit it; however, since the language of Turkey is Turkish, and to ensure that personal names are registered correctly in the registers, these names should be written according to the rules of the Turkish grammar."

33 Treaty with Turkey 1923.

34 Parla (2005) has detailed in the case of Turkish immigrants from Bulgaria how the Turkish state's aspirations to monopolize and enforce the homogenization of the nation's religious and ethnic terrain did not always result in the complete acceptance of the Muslims and/or Turks who came from the former Ottoman territories to the Turkish national body.

35 In 1926, the state rescinded the group rights guaranteed by the Lausanne Treaty (Bakar 2002; Bali 1999), and minority communities were forced to surrender their semi-autonomous status in 
made certain combinations of religion, ethnicity, and language nonsensical at best and a mark of treason at worst, those persons whose identity straddled the accepted ethno-religious categories - such as Armenian Muslim, Jewish Muslim (see Baer 2004), or Christian Turk (see Özyürek 2009b)_found themselves regarded as threats to national unity.

The marking of non-Muslims in the Turkish Republic was part of the regulation of personal names by which Turkish citizens could be accounted for. Naming policies have been a conventional tool used by states to construct a homogeneous national identity through the elimination of distinctive minority names (Caplan and Torpey 2001; Scott, Tehranian, and Mathias 2002; Steedly 1996; Sutherland 1994; Bruck and Bodenhorn, 2006; Watson 1986). The Turkification of the names of non-Muslim minorities has been studied in the context of such homogenization (Başgöz 1999; Brink-Danan 2010; Türköz 2007). The literature on naming treats minority names as a "stigma" (Bering 1992) that marks minorities for exclusion from the purportedly homogeneous nation. In the recent name-change cases, however, personal names also appear as a site of struggle where citizens demand minority rights as members of a recognized minority community in Turkey (Azevedo 1980; Carucci 1984; Khatib 1995). The growing politicization of personal naming practices among Kurds in Turkey also points toward this emergence of name change as a site of minority recognition struggles (Aslan 2009; Ergin 2010; Esen and Gönenç 2008). As a lawyer who took many name-change cases of Armenians related to me, "Name change, in these cases, is a way to confront the state." Therefore, in light of laws regulating the adoption and use of nonTurkish names, one can see that name change, like religious conversion, is a source of anxiety for the state. It disrupts the normative connection the state has established between its own "identification" of citizens at birth and citizens' self-identification/self-naming as members of an ethnic or religious minority (Viswanathan 1998).

Later developments concerning religion and names in the civil registers further consolidated state control. Military coups in 1960, 1972, and 1980 not only suppressed political opposition and economic restructuring but also strengthened the discourse of "equal citizenship," which in the name of order and the state's interests eliminated any room for dissent or difference (Parla 2002). The most important legislation concerning state registers, which came after the 1972 coup, updated and centralized all of the laws and regulations on the civil registrars. While religion had been a feature of identity documentation since the nineteenth century, Article 43 of the 1972 Population Register

exchange for purportedly equal citizenship. Later, after World War II, this protection system ceased to exist altogether when the international doctrine of individual human rights replaced the individually recognized rights of minority groups (Mazower 2004). 
Law $^{36}$ required the national registry to state the religion of every family member in every household in Turkey.

A decision of the Court of Cassation in the year 2000 is illustrative. It demonstrates how name and religion are strictly tied together in defining minority difference, and in the period immediately preceding the late-twentieth century legal reform, this decision became the precedent for refusing name changes in cases where plaintiffs tried to argue for religious conversion as just cause. In this case, a Muslim citizen of Turkey converted in the Greek Orthodox Church to Christianity, and consequently wanted to change his current Turkish name Enis to a Greek one, Teofilos. The local civil court of first instance declined his request, ruling, "It is impossible to bring to agreement the [new] name that is subject to discussion here with our national culture and our customs and tradition." The plaintiff took the case to the Court of Cassation, asking it to annul the First Degree Appeal Court's decision, but it instead ratified the decision with the following ruling: "Religious conversion does not necessarily require a name change. Plaintiff's name, Enis, means [in Turkish] companion, friend; hence no inconvenience emerges by having this name, whichever confession a person belongs to. The fact that the plaintiff was accepted into the Orthodox faith [mezhep] by the Greek Patriarchate by this name [Teofilos] does not establish a just cause for changing the name of the plaintiff who is a Turkish citizen in the civil registers." ${ }^{37}$

In its decision the Court of Cassation devised an authorized definition of religion, as individual confession as registered in the civil records, which has nothing to do with the culture of the religion that is subsequently indicated in the religious identity column of a citizen's identity card. The court's statement that "the plaintiff is a Turkish Citizen" hints at the limits of the rights of citizens. A citizen's name defines the boundaries of the state's sovereignty over its subjects, and a Turkish citizen may not adopt a name that is not in accordance with Turkish "national culture, customs and tradition." The higher court's judgment once again stressed the unalterable link between the self-identification of a citizen by personal names and the (ethnic, religious, linguistic) identification of the Turkish citizen by the state, as embodied in legal practices such as naming. ${ }^{38}$

${ }^{36}$ No. 1587; published in the Official Gazette (Resmi Gazete) in 1972 (hereafter "1972 Population Register Law"). It replaced the law of 1914 and remained in force until enactment of the Population Services Law of 2006 (No. 5490) (hereafter "2006 Population Register Law"). Some of its articles, including the abovementioned Article 43, were changed by an (interim) Law (No. 4826) in 2003.

${ }^{37}$ Cited in Diran Bakar (2002: 274). Unfortunately, the author does not give the decision number, and thus I was unable to obtain the case and its decision numbers.

${ }^{38}$ There is a hint in this case that the plaintiff was most likely asking to rejoin his ancestors' religion or married an Orthodox Greek women and changed his religion accordingly, considering that he specifically stated that he converted in the Greek Orthodox Church. The Greek Orthodox Patriarchate (just like the Armenian Apostolic Patriarchate of Istanbul) does not accept new 
And yet, the civil courts did not reject all name-change requests that gave the reason of religious conversion. One striking example was the case of an Armenian citizen who converted to Islam and wanted to change his name accordingly. In his case the court did not ask for witnesses as the law states it must, though it did require the plaintiff to have a lawyer. His petition was granted in just one session. ${ }^{39}$

Thus, the question whether religious conversion ought to be considered a just cause for changing one's name does not produce the same answer in every case. The judiciary reserves the right to decide this for itself. It is not merely a question about civil procedure, nor is it an example of a discriminatory application of otherwise good, secular laws. On the contrary, all of the laws and regulations of Turkey's secular legal system that I have presented here work to ensure simultaneously that "religion" is a private matter but that the state has final, authoritative say as to both the definition of religion and the question of which denomination a person may profess. Though the Court of Cassation declared religion to be essential to personal status, it also enacted its sovereign authority to decide what religion is, how it is connected to a Turkish citizen, and who may belong to which religious denomination.

One can trace the pre-established legal limits of permissible arguments back to the Turkish Constitution of 1982, Article 24 of which addresses freedom of religion and conscience and provides: "Everyone has the right to freedom of conscience, of belief and of religious conviction. Acts of worship, religious services and ceremonies may be conducted freely, provided they do not violate the provisions of Article 14 of the Constitution." Then again, upon considering Article 14/1 one realizes that the real concern for Turkish legal authorities is "abuse of rights": "None of the rights and freedoms embodied in the Constitution shall be exercised with the aim of violating the indivisible integrity of the state with its territory and nation, and endangering the existence of the democratic and secular order of the Turkish Republic based upon human rights" (my emphasis). Here, the Constitution conceptualizes the Turkish Republic as an entity that could be endangered by its citizens using (defined as "abusing") fundamental rights and freedoms in certain ways.

Today, in light of Article 14/1 and the abovementioned articles of the Turkish Criminal Code, the court cases of converts are basically about the state's right to defend the indivisible integrity of its territory and nation. Further, this integrity should prevail over all other rights, including those of religion and name that are tightly attached to the individual by law. Next I

converts, but only conversions of the descendants of community members or conversion as a way of marriage.

39 Decision of the Beyoğlu Civil Court (3. Asliye Hukuk Mahkemesi), Esas No. 2008/312, Karar No. 2008/406. 
turn to the recent policies of religious tolerance in order to analyze further the entanglements of religion and names in the courts, and how religion acquired a new definition in these same courts during the reform period.

TOLERANCE AS A NEW MODE OF REGULATION: RELIGION AS CULTURE

Scholars have discussed extensively the concept of tolerance within the Turkish context as the tolerance of religious, cultural, and ethnic differences within a homogeneously imagined Turkish nation (Kaya 2013). Several have grappled with the concept as it specifically relates to Turkey's religious minorities, asking whether tolerance is in fact a political project centered on a Turkish majority living together with non-Muslim minorities (Brink-Danan 2011; Mills 2010). ${ }^{40}$ Nevertheless, this body of work has not tried to analyze tolerance as a political concept that governs and excludes minorities simultaneously, nor has it fully tackled the relationship between the law and the limits of religious freedom in Turkey. ${ }^{41}$ What role does the law play in the construction of tolerance discourse? What role has it played in the establishment of that discourse's central categories such as religion?

In the course of my research, population registrars all reacted to my inquiries about problems with name-change cases in the same way. "You can't find anything problematic," I was repeatedly told. "It is only correction of records. Especially since the European Union-led reforms, there are no controversial cases left." But against their claims, there are still name-change cases that define the limits of the toleration of religious difference. The court cases I collected during my fieldwork in the First Degree Appeal Courts (Asliye Hukuk Mahkemeleri) in Istanbul illustrate a shift that has occurred in the definitions of religion and religious freedom as a result of the reformed legal measures.

One case from 2007, the same year as the Agop/Mehmet case, is especially revealing since it exemplifies the redefinition of religion in the legal realm. The local court's decision reads:

The lawyer of the plaintiff states in the petition directed to the court that, as it can be also understood from the civil records, his client is a Turkish citizen and belongs to the Christian confession, and his name is recorded as "Ramazan," and his client is never uncomfortable with his name, respects the religion of Islam as well as any other religion, but since he belongs to the Christian faith and since the name "Ramazan" does not represent his religion and its cultural character, [the plaintiff] requests to change his name to

\footnotetext{
40 The relationship between religious conversion and tolerance is not scrutinized in the republican period, but for an excellent and rare discussion of tolerance in the context of conversion in the Ottoman Empire, see Baer, Makdisi, and Shryock 2005. Also see Barkey 2008; and Rodrigue 1995.

${ }^{41}$ We should also note here that discussions of tolerance in Turkey are very much limited to an analysis of the treatment of non-Muslim minorities. Kurdish and Alevi minorities, the two major minority populations in Turkey today, are rarely included.
} 
Daniel, the name of a prophet who lived in one of the historical places in southern Turkey. ${ }^{42}$

The lawyer's petition is striking. He frames the conversion and the subsequent name change in cultural terms by emphasizing the native character of the prophet Daniel with regard to Turkey's national geography. ${ }^{43}$ As this lawyer explained to me, he tried to develop alternative, non-threatening cultural explanations for religious conversion and name change. He deployed a culturalist argument by emphasizing the common history of monotheistic religions as justification for the name change. Accordingly, his reasoning emphasized the multi-religious character of the ancient lands on which the Republic of Turkey was founded. He hoped this would avoid the appearance that his client was challenging the authoritarian nationalist understanding of Turkish culture and customs (Tambar 2010), since it coincided with the government's recent efforts in the wake of the European Union-led legal reforms to underscore tolerance for minority religions and cultures (White 2013).

The local court rejected this petition on the grounds that religious conversion does not establish a just cause for name change. The lawyer then took the case to the Court of Cassation, which overruled the lower court's decision and approved the name change: "The plaintiff converted to Christianity.... His request to change his name, after his conversion, to another one that is in accordance with what he believes to represent his religion and its cultural character, should be accepted as a just cause" (my emphasis).

The decision was subsequently celebrated as a sign of growing religious tolerance. How can we account for the striking difference between how the Agop/Mehmet and Daniel/Ramazan cases were handled in the courts, and their different outcomes? I think that it is wrong to see this dichotomy as a failure of Turkish secularism to provide religious freedom. Senem Aslan (2009) urges that when we try to understand the differences between the local level bureaucratic and judicial state apparatuses (such as the local courts) and the Court of Cassation, we consider the positions of different state actors. She argues that when analyzing state policies we should not see certain state policies, such as the ban on Kurdish names, as "an absolute and permanent rule that remained valid at all times across similar cases" (ibid.: 2). According to Aslan, the incoherent nature of state policies in Turkey is the result of a "subtle contestation" between the local- and higher-level bureaucracies and judiciaries. While I agree with her nuanced discussion of

42 Decision of the Beyoğlu Civil Court (3. Asliye Hukuk Mahkemesi), Esas No. 2007/172, Karar No. 2007/172.

${ }^{43}$ Daniel is the Christian version of a Turkish name, Danyal. The Book of Daniel is part of the Hebrew canon, but not of the Qur'an. However, he is accepted as a prophet in Islam, since he appears in one of the hadiths (Köksal 2004: 269-76). In Turkish popular Islam Daniel retains a significant place due to the belief that his gravesite is in Tarsus (Mersin), Southern Turkey, also the hometown of Saul (Saint Paul). Inanc Turizmi n.d. 
state power, I do not entirely concur with Aslan's conclusion that incoherence is due solely to a "subtle contestation" between different state actors (ibid.: 3). Regarding the Armenian name-change cases, I offer a different interpretation of the discrepancy between the different courts, one that sees incoherence as a fundamental, inherent aspect of the workings of the state. As these cases illustrate, incoherence is an "active principle of secularism"; that is to say, "the principle that the state has the power and authority to decide what should count as essentially religious and what scope it can have in social life" (Agrama 2010: 503, see also Agrama 2006). With Agrama's analysis of Egyptian law at hand, we can argue that the Turkish state's attitudes toward the rule of law are themselves complex, bound up as they are with questions of sovereignty and governmentality within the modern state.

I argue that the different outcomes serve as an exercise of the state's regulatory capacity, just as they did in the pre-reform era. In both cases, one can see that the struggle was not just about the name change but also the definitions of religious difference. The strategy of Ramazan/Daniel's lawyer to address religion in a culturalist frame was successful in the upper court. Evidently, a vision of national territory as a homeland for different religious cultures complements the religious tolerance of the legal reforms that eased conversion. Although the upper court still considered both name and religion as tied to the personal status of the individual citizen, its argument redefined religion as having a cultural character and an individual's name as representing this character. We thus witness a change in how the law defines the relationship between religion and one's name in Turkey's post-reform era. The courts no longer regulate religion as if it bore absolutely no relationship to ethnic belonging; instead, they redefine religion - and subsequently ethnicity — as a cultural trait. The party that seeks to assert cultural difference phrased as religious freedom is not the population of disempowered minorities, but rather the courts. This reverses the antinomy between culture and the law (see Comaroff and Comaroff 2004; Hamilton 2009; Yudice 2003, cf. Merry 2000). The law has embraced culture as the central operating category in cases of name-change after religious conversion. Once religion is defined as a cultural trait of individual citizens, religious conversion is tolerated as a claim to cultural difference. ${ }^{44}$ The Court of Cassation once more enacted its sovereign authority to decide what religion is, how it is connected to a Turkish citizen, and what it means to belong to a religious denomination.

The different outcomes of the Daniel and Agop cases, I maintain, provide vital insights into the particularities of tolerance talk in Turkey. They are not just another instance of the "recent global renaissance of tolerance talk" that

\footnotetext{
44 There is also a rich literature on the judiciary's role in maintaining the status quo with respect to policies regarding religion, minorities, and politics in Turkey (Bayır 2013; Belge 2006; Koḡacioğlu 2004; Shambayati and Kirdis 2009).
} 
is characterized by the culturalization of political conflict (Brown 2006: 2). In the case of Daniel, the court utilized tolerance "as a unique way of sustaining the threatened entity" (ibid.: 27), as is clear in the references to minority difference and the multi-ethnic, multi-religious (pre)history of the Turkish Republic using manageable terms such as "Anatolian cultural heritage" (Tambar 2010). In contrast, the name-change cases of the descendants of forcibly converted Armenians, exemplified by Agop/Mehmet, triggered legally sanctioned resentment vis-à-vis Armenian claims about the violent fate of their ancestors. Islamized Armenians who appear in the courts and implicitly engage in the forbidden mentioning of genocide are perceived as threats to the Turkish state's integrity and as violating the established limits of tolerance in postreform Turkey.

My intent here is to show through these cases that tolerance does not resolve difference, but rather "tames" it. ${ }^{45}$ The courts that adjudicate namechange cases manage antagonism toward unauthorized claims to difference. In Turkey, the discourse of tolerance works through this redefinition of religion as culture, and religious freedom as an individual's right to belief. In the case of Agop, the explicit reference to the ethnic aspect of his request for a name change prevented this culturalization of religion from taking place. The namechange cases of the descendants of forcibly Islamized Armenians challenge both the original law's authorized definition of religion as individual belief and the communal culture as redefined after the reform. These cases touch on undesirable and illegal topics, including first and foremost the Armenian Genocide. The tolerance discourse has hardly changed the Turkish state's "aversion," following Brown's definition, to any mention of the fate of Armenians at the end of the Ottoman Empire and throughout the history of the Republic. For this reason, a non-Muslim religious minority that has been designated an object of tolerance remains marked as a community of undesirable subjects who contravene the established limits for name change and, consequently, for religious tolerance.

Unlike the Western liberal democracies that are the subject of Brown's study, in Turkey the problem of "tolerance talk" cannot be presented as a moral claim to one's "own civilization" at the expense of the immigrant, Muslim, "barbaric" other. In Turkey, the conflicts that tolerance discourse aims to tame and depoliticize are inextricably tied to the history of the nationstate, as well as to discourses of difference that circulate internationally. Tolerance is a strictly national matter that tries to regulate a thin line between the legal and illegal. This fact points to another difference between the Turkish

45 See Kabir Tambar's (2010: 659) discussion of philosopher Chantal Mouffe's (2005) argument about pluralistic politics working to tame antagonism between social constituencies. Tambar argues, "The processes and practices that tame conflict can also function to de-politicize disputes" (ibid.: 659). Here, I adopt Tambar's use of the term. 
context and the global resurgence of tolerance. Contrary to Brown's argument that "within secular liberal democratic states it is safe to say that tolerance functions politically and socially, but not legally" (2006: 10), I suggest that in Turkey one of its main functions is in fact legal. ${ }^{46}$ It is not an "alternative to full legal equality," but instead defines which claims are legal and which claims are not. In this sense, political conflict in Turkey does not only become culturalized but also legalized. In the case of Islamized Armenians, the legal context of religious tolerance serves to cover up the political struggles and injustices perpetrated in the past and present. Thus tolerance-based legislation in Turkey has replaced, but not annulled, the pre-reform regulation of difference by legal authorities. The court cases are therefore grounds on which take place the battles over what constitutes religion and how it should be regulated. By continuing to adjudicate the terms of just cause, the courts define and redefine not just whether religion applies, but what religion is. Hence the management of religious and ethnic boundaries by law remains more or less intact in regulations pertaining to name change.

\section{CONCLUSION}

On the international stage, the AKP government is upheld as a model of the harmonious coexistence of democracy and liberal Islam for emulation across the Middle East. However, this new model is, as yet, under-analyzed. It is a topic that demands special scrutiny now, on the eve of Turkey's new constitution, and in light of the ongoing arbitrary detentions and political repression targeting various oppositional groups, such as persons involved in the Kurdish rights struggle, university students, and other political opponents of the state. The excessive repression of the Gezi protests during June 2013 dealt a serious blow to the new Turkish regime's legitimacy.

"What is called Turkish secularism," Özyürek states, "is a manifestation of ideological and religious state centralization" (2009b: 411; see also Parla and Davison 2008). Her analysis of secularism as a nationalist matter holds true in post-reform Turkey. We can further nuance her insight with a focus on the post-reform notion of religious tolerance as an instrumental vision of culture. In the Turkish courts, the situation is significantly more complicated. There, ethnicity and religion, the historical and the legal, and categories of "Turkish" and "Armenian" are all conjured on the way to legal justice, through shifting authorized definitions of religion. The historical context of name change and the conversions of descendants of forcibly Islamized Armenians push the limits of existing understandings of freedom of religion in Turkey, which renders visible historical injustices that cannot be resolved simply through the notion of "religious tolerance" in the courts. Law is critical

\footnotetext{
${ }^{46}$ For another argument on the distinctive relation between law and morality as the precarious basis for religious tolerance, see Asad 2003: 183-84.
} 
to the mode of rule that we call secularism today, not in the way it confines religion to the private realm (e.g., Kuru 2009), but rather by the way it defines the central categories of religion and personal belonging. The politics of tolerance in today's Turkey, like the regulation of the pre-reform era, highlights the fact that "the active principle of secularism is a principle of sovereign state power" (Agrama 2010: 510; see also Asad 2006).

My analysis here has shown that the relationship between secularism, the law, and religion cannot be reduced to the distinction between secular and Islamic policies, or Islam's compatibility or incompatibility with secularism. Cihan Tugal argues that there was a "(thorough yet incoherent and indecisive) shift" in Turkey from "hegemonic nationalism" [Kemalist secularism] that sought to assimilate minorities, to "corporate nationalism" [the AKP government] that seeks to lock minorities into "restrictive cultural identities" (2009: 101). With Tugal's claims in hand, one can argue that more is at stake politically in the intolerability of the name-change demands made in Turkey's secular courts by descendants of forcibly Islamized Armenians. These trials seek to create legal subjects who must now define their rights on the basis of an individual right to belief, but also culturalize their religious belonging in order to join the authoritatively defined "national culture." The courts, at every level, play a crucial role in this definition.

The recent discourse of religious tolerance creates good minorities and bad minorities, which are judged by their contribution, or lack thereof, to a fundamentally national culture. In this sense, "tolerance talk" in Turkey should be evaluated as a legal reform undertaken by a conservative nationalist movement, and this is why it has been incapable of recognizing the descendants of forcibly Islamized Armenians as citizens of Turkey who are legally Armenian and carry Armenian names.

\section{REFERENCES}

Abu El-Haj, Nadia. 2012. The Genealogical Science: The Search for Jewish Origins and the Politics of Epistemology. Chicago: University of Chicago Press.

Agrama, Hussein Ali. 2006. Asking the Right Question: Two Engagements with Islam and Modernity. Political Theory 35, 4: 647-56.

Agrama, Hussein Ali. 2010. Secularism, Sovereignty, Indeterminacy: Is Egypt a Secular or a Religious State? Comparative Studies in Society and History 52, 3: 495-523.

Akan, Murat. 2011. The Infrastructural Politics of Laiklik in the Writing of the 1961 Turkish Constitution. Interventions: International Journal of Postcolonial Studies 13, 2: 190-211.

Akçam, Taner. 2004. From Empire to Republic: Turkish Nationalism and the Armenian Genocide. London: Zed Books.

Algan, Bülent. 2008. The Brand New Version of Article 301 of Turkish Penal Code and the Future of Freedom of Expression Cases in Turkey. German Law Journal 9, 12: 2237-52.

Altınay, Ayşe Gül and Yektan Türkyılmaz. 2011. Unraveling Layers of Gendered Silencing: Converted Armenian Survivors of the 1915 Catastrophe. In Amy Singer, 
Christoph K. Neumann, and Selçuk Akşin, Somel, eds., Untold Histories of the Middle East: Recovering Voices from the 19th and 20th Centuries. London: Routledge, 25-53.

Altınay, Ayşe Gül and Fethiye Çetin. 2009. Torunlar [Grandchildren]. Istanbul: Iletisim Press.

Asad, Talal. 2003. Formations of the Secular: Christianity, Islam, Modernity. Stanford: Stanford University Press.

Asad, Talal. 2006. Trying to Understand French Secularism. In Hent de Vries and Lawrence E. Sullivan, eds., Political Theologies: Public Religions in a Post-Secular World. Bronx, N.Y: Fordham University Press, 494-526.

Aslan, Senem. 2009. Incoherent State: The Controversy over Kurdish Naming in Turkey. European Journal of Turkish Studies (online). At: http://ejts.revues.org/ index4142.html (accessed 5 Apr. 2012]).

Ateşyan, Aram. 2012. Türkiyede yıllık 60-70 Ermeni Vaftiz Edilip Hıristiyanlaştırılıyor. Ermenihaber (online). At: http://www.ermenihaber.am/?lang_id=1\&news_=4\&cur_ news $=116$ (accessed 31 July 2013).

Aybay, Rona. 2004. Vatandaşlık Hukuku [Citizenship law]. Istanbul: Bilgi Üniversitesi Yayinlari.

Azevedo, Eliane S. 1980. Anthropological and Cultural Meaning of Family Names in Bahia, Brazil. Current Anthropology 21, 3: 360-63.

Baer, Marc. 2004. The Double Bind of Race and Religion: The Conversion of the Dönme to Secular Turkish Nationalism. Comparative Studies in Society and History 46, 4: 682-708.

Baer, Marc. 2009. The Dönme: Jewish Converts, Muslim Revolutionaries, and Secular Turks. Stanford: Stanford University Press.

Baer, Marc, Ussama Makdisi, and Andrew Shryock. 2005. Tolerance and Conversion in the Ottoman Empire: A Conversation. Comparative Studies in Society and History 51, 4: 927-40.

Bakar, Diran. 2002. Uygulamada Ayrımcılık Örnekleri ve Azınlık Vakıflarının Sorunları. In İbrahim O. Kaboglu, ed., Ulusal, Ulusalüstü ve Uluslararası Hukukta Azınlık Hakları. İstanbul: İstanbul Barosu İnsan Hakları Merkezi Yayını, 262-75.

Bali, Rifat N. 1999. Cumhuriyet yillarinda Turkiye Yahudileri: Bir Turklestirme Seruveni, 1923-1945 [Turkish Jews in the Republican Era: An adventure of Turkification, 1923-1945]. Istanbul: Iletisim Yayinlari.

Barkey, Karen. 2008. Empire of Difference: The Ottomans in Comparative Perspective. Cambridge: Cambridge University Press.

Başgöz, İlhan. 1999. The Meaning and Dimension of Change of Personal Names in Turkey. In Kemal Silay, ed., Turkish Folklore and Oral Literature: Selected Essays of İlhan Başgöz. Bloomington: Indiana University Press.

Bayır, Derya. 2013. Minorities and Nationalism in Turkish Law. London: Ashgate.

Belge, Ceren. 2006. Friends of the Court: The Republican Alliance and Selective Activism of the Constitutional Court of Turkey. Law and Society Review 40, 3: 653-92.

Bering, Dietz. 1992. The Stigma of Names: Antisemitism in German Daily Life, 18121933. Ann Arbor: University of Michigan Press.

Bloxham, D. and Fatma M. Göçek. 2008. The Armenian Genocide. In Dan Stone, ed., The Historiography of Genocide. London: Palgrave Macmillan, 344-72.

Brink-Danan, Marcy. 2010. Names that Show Time: Turkish Jews as "Strangers" and the Semiotics of Reclassification. American Anthropologist 112, 3: 384-96.

Brink-Danan, Marcy. 2011. Jewish Life in Twenty-First-Century Turkey: The Other Side of Tolerance. Bloomington: Indiana University Press. 
Brown, Wendy. 1995. Rights and Losses. In States of Injury: Power and Freedom in Late Modernity. Princeton: Princeton University Press, 96-134.

Brown, Wendy. 2006. Regulating Aversion: Tolerance in the Age of Identity and Empire. Princeton: Princeton University Press.

Bruck, Gabriele vom and Barbara Bodenhorn, eds. 2006. The Anthropology of Names and Naming. Cambridge: Cambridge University Press.

Cagaptay, Soner. 2006. Islam, Secularism and Nationalism in Modern Turkey: Who Is a Turk? London: Routledge.

Caplan, Jane and John C. Torpey. 2001. Documenting Individual Identity: The Development of State Practices in the Modern World. Princeton: Princeton University Press.

Carucci, Laurence M. 1984. Significance of Change or Change of Significance: A Consideration of Marshallese Personal Names. Ethnology 23, 2: 143-55.

Clifford, James. 1988. Identity in Mashpee. In The Predicament of Culture: TwentiethCentury Ethnography, Literature, and Art. Cambridge: Harvard University Press, 277-348.

Comaroff, John and Jean Comaroff. 2004. Criminal Justice, Cultural Justice: The Limits of Liberalism and the Pragmatics of Difference in the New South Africa. American Ethnologist 31, 2: 188-204.

Connolly, Jennifer. 2009. Forbidden Intimacies: Christian-Muslim Intermarriage in East Kalimantan, Indonesia. American Ethnologist 36, 3: 492-506.

Connolly, William E. 1999. Why I Am not a Secularist. Minneapolis: University of Minnesota Press.

Coutin, Susan Bibler. 1995. Smugglers or Samaritans in Tucson, Arizona: Producing and Contesting Legal Truth. American Ethnologist 22, 3: 549-71.

Dadrian, Vahakn. 1995. The History of the Armenian Genocide: Ethnic Conflict from the Balkans to Anatolia to the Caucasus. Providence and Oxford: Berghahn Books.

Demiralp, Tunç. 2003. Nesep Nüfus ve Kişisel Hukuk Davaları [Personal status, and civil registry cases]. Istanbul: Alfa Basim Yayim Dağıtım.

Deringil, Selim. 2000. "There Is no Compulsion in Religion": On Conversion and Apostasy in the Late Ottoman Empire: 1839-1856. Comparative Studies in Society and History 42, 3: 547-75.

Deringil, Selim. 2012. Conversion and Apostasy in the Late Ottoman Empire. Cambridge: Cambridge University Press.

Ekşi, Nuray. 2008. Vatandaşlık Hukukumuzda Türkçe Olmayan Ad ve Soyad Meselesi [The issue of non-Turkish first and last names in our citizenship law]. İstanbul: Beta Yayinlari.

Ergin, Ayşe Dicle. 2010. Azinlik Dillerinin Kullanimi Konusunda Türkiye Nerede Duruyor? [Where does Turkey stand with regard to the use of minority languages?]. AUHFD (journal of Ankara University Law School) 59, 1: 1-34.

Esen, Selin and Levent Gonenç. 2008. Religious Information on Identity Cards: A Turkish Debate. Journal of Law and Religion 23, 2: 579-603.

European Commission against Racism and Intolerance (ECRI). 1999. First Report on Turkey (online). At: http://hudoc.ecri.coe.int/XMLEcri/ENGLISH/Cycle_01/ 01_CbC_eng/01-cbc-turkey-eng.pdf (accessed 31 Jan. 2014).

European Commission against Racism and Intolerance (ECRI). 2001. Second Report on Turkey. (online). At: http://hudoc.ecri.coe.int/XMLEcri/ENGLISH/Cycle_02/ 02_CbC_eng/02-cbc-turkey-eng.pdf (accessed 31 Jan. 2014).

European $\bar{C}$ ommission against Racism and Intolerance (ECRI). 2005. Third Report on Turkey (online). At: http://hudoc.ecri.coe.int/XMLEcri/ENGLISH/Cycle_03/ 03_CbC_eng/TUR-CbC-III-2005-5-ENG.pdf (accessed 31 Jan. 2014).

Fernando, Mayanthi L. 2010. Reconfiguring Freedom: Muslim Piety and the Limits of Secular Law and Public Discourse in France. American Ethnologist 37, 1: 19-35. 
Gordillo, Gastón. 2006. The Crucible of Citizenship: ID-Paper Fetishism in the Argentinean Chaco. American Ethnologist 33, 2: 162-76.

Gözaydın, İştar B. 2009. Diyanet: Türkiye Cumhuriyeti'nde Dinin Tanzimi. İstanbul: İletişim Publishing.

Hamilton, Jennifer 2009. Indigeneity in the Courtroom: Law, Culture, and the Production of Difference in North American Courts. New York: Routledge.

Hız, Yüksel and Zekeriya Yılmaz. 2004. Ad, Adın Çeşitleri, Kazanılması, Değişsirilmesi ve Ad Üzerindeki Hakkın Korunması. Adalet Dergisi [journal of the Justice Ministry] 18. At: http://www.yayin.adalet.gov.tr/18_sayi.htm (accessed 5 Apr. 2014).

İnanç Turizmi. n.d. Mersin Il Kultur ve Turizm Mudurlugu Website (online). At: http://www.mersinkulturturizm.gov.tr/TR,73394/inanc-turizmi.html (accessed 8 Sept. 2013).

Karaca, Banu. 2011. Images Delegitimized and Discouraged: Explicitly Political Art and the Arbitrariness of the Unspeakable. New Perspectives on Turkey 45: 155-83.

Karahanoḡulları, Özlem E. 2010. Danıștay Kararlarinda Din, Vicdan ve Düsünce Özgürlügü (online). At: http://www.Yargitay.gov.tr/abproje/belge/sunum/rt5/Karahanogullari_DinOzgurlugu.pdf (accessed 24 Apr. 2013).

Kaya, Ayhan. 2013. Europeanization and Tolerance in Turkey: The Myth of Toleration. Basingstoke, UK: Palgrave MacMillan.

Khatib, Syed Malik. 1995. Personal Names and Name Changes. Journal of Black Studies 25, 3: 349-53.

K1lıç, Ümit. 2010. İsim ve Soyisim Hakkinin Avrupa İnsan Haklari Sözleşmesi Kapsaminda Korunmasi [Protection of right to a name and a surname under the European Convention on Human Rights]. TBMM Dergisi [journal of the Turkish Grand National Assembly] 89: 242-76.

Kirişci, Kemal. 2009. Mirage or Reality: Post-National Turkey and Its Implication for Immigration. In EUI RSCAS 2009/14, CARIM Research Report.

Koğacioğlu, Dicle. 2004. Progress, Unity and Democracy: Dissolving Political Parties in Turkey. Law and Society Review 38, 3: 433-61.

Köksal, M. Asım. 2004. Peygamberler Tarihi [History of the Prophets]. Istanbul: Türkiye Diyanet Vakfi Yayınları.

Konuralp, Okan. 2010. Artık kimliklerine Hiristiyan yazdırıyorlar. Hurriyet Newspaper (online) 21 Sept. At: http://www.hurriyet.com.tr/gundem/15828167.asp (accessed 5 Apr. 2013).

Kravel-Tovi, Michal. 2012. Rite of Passing: Bureaucratic Encounters, Dramaturgy, and Jewish Conversion in Israel. American Ethnologist 39, 2: 371-88.

Kurban, Dilek. 2003. Confronting Equality: The Need for Constitutional Protection of Minorities on Turkey's Path to the European Union. Columbia Human Rights Law Review 151, 35: 151-214.

Kuru, Ahmet. 2009. Secularism and State Policies toward Religion: The United States, France, and Turkey. Cambridge: Cambridge University Press.

Law to Change Certain Articles of the Population Register Law No: 4826. 2003. Official Gazette of the Republic of Turkey: At: http:/www.resmigazete.gov.tr/eskiler/2003/03/ 20030320.htm (accessed 31 Jan. 2014).

Longman, Timothy. 2001. Identity Cards, Ethnic Self-Perception, and Genocide in Rwanda. In Jane Caplan and John Torpey, eds., Documenting Individual Identity: The Development of State Practices in the Modern World. Princeton: Princeton University Press, 345-59.

Mahmood, Saba. 2012. Religious Freedom, the Minority Question, and Geopolitics in the Middle East. Comparative Studies in Society and History 15, 2: 418-46. 
Mazower, Mark. 2004. The Strange Triumph of Human Rights, 1933-1950. Historical Journal 47, 2: 379-98.

McClay, Wilfred M. 2001. Two Concepts of Secularism. Journal of Policy History 13, 1 : 47-72.

Merry, Sally E. 2000. Colonizing Hawaì: The Cultural Power of Law. Princeton: Princeton University Press.

Mills, Amy. 2010. Streets of Memory: Landscape, Tolerance, and National Identity in Istanbul. Athens: University of Georgia Press.

Molokotos-Liederman, Lina. 2007. The Greek ID Card Controversy: A Case Study of Religion and National Identity in a Changing European Union. Journal of Contemporary Religion 22, 2: 187-203.

Mouffe, Chantal. 2005. On the Political. New York: Routledge.

Navaro-Yashin, Yael. 2002. Faces of the State: Secularism and Public Life in Turkey. Princeton: Princeton University Press.

Noiriel, Gerard. 2001. The Identification of the Citizen: The Birth of Republican Civil Status in France. In Jane Caplan and John Torpey, eds., Documenting Individual Identity: The Development of State Practices in the Modern World. Princeton: Princeton University Press, 28-48.

Ölmez, Mehmet. 2000. Dil Devrimi Sonras1 Ad ve Soyadlarımız [Our first and last names after the language revolution]. Türklük Bilgisi Araştırmaları 24, 2: 107-17.

Özgül, Ceren. 2013. From Muslim Citizen to Christian Minority: Tolerance, Secularism and Return Conversions in Turkey. PhD diss., Department of Anthropology, The Graduate Center, City University of New York.

Özuzun, Yervant. 2006. Gitmek mi Zor, Kalmak mı? Gidenler Kalanlar ve ‘Dönenler!' [Is it hard to leave or stay? The ones who left, the ones who stayed, and the ones who "converted!']. Hyetert (online) At: http://www.hyetert.com/yazi3.asp?s=0\&AltYazi=Makaleler\%20\%3E\%20Genel\&Id=249\&Sayfa=1\&DilId=1 (accessed 9 Dec. 2010).

Özyürek, Esra. 2006. Nostalgia for the Modern: State Secularism and Everyday Politics in Turkey. Durham: Duke University Press.

Özyürek, Esra. 2009a. Convert Alert: German Muslims and Turkish Christians as Threats to Security in the New Europe. Comparative Studies in Society and History 51, 1: 91-116.

Özyürek, Esra. 2009b. Christian and Turkish: Secularist Fears of a Converted Nation. Comparative Studies of South Asia, Africa and the Middle East 29, 3: 398-412.

Pandey, Gyanendra. 1999. Can a Muslim Be an Indian? Comparative Studies in Society and History 41, 4: 608-29.

Parla, Ayşe. 2005. Terms of Belonging: Turkish Immigrants from Bulgaria in the Imagined Homelan. PhD diss., Department of Anthropology, New York University.

Parla, Ayşe. 2011. Undocumented Migrants and the Double Binds of Rights Claims. Differences: A Journal of Feminist Cultural Studies 22 1: 64-89.

Parla, Taha. 2002. Türkiye'de Anayasalar [Constitutions in Turkey]. Istanbul: Iletisim Yayınları.

Parla, Taha and Andrew Davison. 2008. Secularism and Laicism in Turkey. In Janet R. Jakobsen and Ann Pellegrini, eds., Secularisms. Durham: Duke University Press, 58-75.

Population Register Law No. 1587. 1972. Official Gazette of the Republic of Turkey. At: http://www.nvi.gov.tr/Files/File/Mevzuat/Yururlukten_Kaldirilanlar/Kanun/pdf/1587\% 20 say $\%$ C4\%B11\%C4\%B1\%20N\%C3\%9CFUS\%20KANUNU.pdf (accessed 31 Jan. 2014).

Population Register Law No. 5490. 2006. Official Gazette of the Republic of Turkey. At: http://www.tbmm.gov.tr/tutanaklar/KANUNLAR_KARARLAR/kanuntbmmc090/ kanuntbmmc090/kanuntbmmc09005490.pdf (accessed 31 Jan. 2014). 
Povinelli, Elizabeth A. 2002. The Cunning of Recognition: Indigenous Alterities and the Making of Australian Multiculturalism. Durham: Duke University Press.

Resmen 'Ermeni' olmak için gitti. 2008. Samanyolu Haber (online). At: http://www. samanyoluhaber.com/gundem/Resmen-Ermeni-olmak-icin-gitti/187268/ (accessed 5 Feb. 2013).

Rodrigue, Aron, 1995. Difference and Tolerance in the Ottoman Empire. Interview by Nancy Reynolds. Stanford Humanities Review 5: 81-92.

Scassa, Teresa. 1996. National Identity, Ethnic Surnames and the State. Canadian Journal of Law and Society 11, 2: 167-91.

Scott, J. C., J. Tehranian, and J. Mathias. 2002. The Production of Legal Identities Proper to States: The Case of the Permanent Family Surname. Comparative Studies in Society and History 44, 1: 4-44.

Seeman, Don. 2009. One People, One Blood: Ethiopian-Israelis and the Return to Judaism. New Brunswick, N.J.: Rutgers University Press.

Sevinçli, Efdal. 2006. Adlarimiz ve Soyadlarimizda Yasayan Dil Devrimi [The Language revolution that survives in our first and last names]. Journal of Yasar University 1, 3: 277-92.

Shambayati, Hootan and Esen Kirdis. 2009. In Pursuit of "Contemporary Civilization": Judicial Empowerment in Turkey. Political Research Quarterly. 62, 4: 767-80.

Steedly, Mary Margaret. 1996. The Importance of Proper Names: Language and "National" Identity in Colonial Karoland. American Ethnologist 23, 3: 447-75.

Sullivan, Winnifred Fallers. 2005. The Impossibility of Religious Freedom. Princeton: Princeton University Press.

Suny, Ronald Grigor and Fatma Müge Göçek. 2011. Introduction: Leaving It to the Historians. In Ronald Grigor Suny, Fatma Muge Göçek, and Norman M. Naimark, eds., A Question of Genocide: Armenians and Turks at the End of the Ottoman Empire. Oxford: Oxford University Press.

Sutherland, Anne. 1994. Gypsy Identity, Names, and Social Security Numbers. PoLAR: Political and Legal Anthropology Review 17, 2: 75-84.

Tambar, Kabir. 2010. The Aesthetics of Public Visibility: Alevi Semah and the Paradoxes of Pluralism in Turkey. Comparative Studies in Society and History 52, 3: $652-79$.

Taşpınar, Ömer. 2007. The Old Turks' Revolt: When Radical Secularism Endangers Democracy. Foreign Affairs 86, 6: 114-30.

Taylor, Charles. 1994. The Politics of Recognition. In Amy Gutmann, ed., Multiculturalism: Examining the Politics of Recognition. Princeton: Princeton University Press.

Taylor, Charles. 1998. Modes of Secularism. In R. Bhargava, ed., Secularism and Its Critics. Dehli: Oxford University Press, 31-53.

Treaty with Turkey and other Instruments Signed at Lausanne. 1923. Ministry of Foreign Affairs of the Republic of Turkey (website). At: http://www.mfa.gov.tr/ treaty-with-turkey-and-other-instruments-signed-at-lausanne.en.mfa (accessed 3 Jan. 2014).

Trenz, Hans J. 2007. Reconciling Diversity and Unity_Language Minorities and European Integration. Ethnicities 7, 2: 157-85.

Tugal, Cihan. 2009. Passive Revolution: Absorbing the Islamic Challenge to Capitalism. Stanford: Stanford University Press.

Turkey's Leader Counters French Law with Accusations of Colonial-Era Genocide. 2011. New York Times, 24 Dec. At: http://www.nytimes.com/2011/12/24/world/europe/ turkey-lashes-out-over-french-bill-about-genocide.html?_r=0 (accessed 29 Dec. 2013).

Türköz, Meltem. 2007. Surname Narratives and the State-Society Boundary: Memories of Turkey's Family Name Law of 1934. Middle Eastern Studies 43, 6: 893-908. 
Ünal vs. Turkey. Judgment of 16 November 2004, No. 48616/99. 2004. At: http://hudoc. echr.coe.int/sites/eng-press/pages/search.aspx?i=003-1190332-1236514 (accessed 29 Dec. 2013).

Üngör, Ugur Ümit. 2011. The Making of Modern Turkey: Nation and State in Eastern Anatolia, 1913-50. Oxford: Oxford University Press.

U.S. Bureau of Democracy, Human Rights, and Labor, Department of State. 2001. International Religious Freedom Report, Turkey. At: www.state.gov/g/drl/rls/irf/2001/ 5694.htm (accessed 30 Aug. 2013).

U.S. Bureau of Democracy, Human Rights, and Labor, Department of State. 2011. International Religious Freedom Report, Turkey. At: http://www.state.gov/j/drl/rls/irf/ 2011/eur/192871.htm (accessed 30 Aug. 2013).

van der Veer, Peter. 2001. Imperial Encounters: Religion, Nation, and Empire. Princeton: Princeton University Press.

Viswanathan, Gauri. 1998. Outside the Fold: Conversion, Modernity, and Belief. Princeton: Princeton University Press.

Watson, Rubie S. 1986. The Named and the Nameless: Gender and Person in Chinese Society. American Ethnologist 13, 4: 619-31.

White, Jenny. 2013. Muslim Nationalism and the New Turks. Princeton: Princeton University Press.

Yavuz, M. Hakan. 2003. The Case of Turkey. Daedalus 132, 3 (special issue, "Secularism and Religion"): 59-61.

Yeğen, Mesut. 2004. Citizenship and Ethnicity in Turkey. Middle Eastern Studies 40, 5: 682-708.

Yngvesson, Barbara and Susan Bibler Coutin. 2006. Backed by Papers: Undoing Persons, Histories, and Return. American Ethnologist 33, 2: 177-90.

Yudice, George. 2003. The Expediency of Culture: Uses of Culture in the Global Era. Durham: Duke University Press.

\begin{abstract}
Over the last fifteen years, hundreds of Muslim citizens claiming Armenian descent have submitted petitions to Turkey's secular legal authorities asking for changes to both their name and religion in the public record. In this article, I discuss the name-change cases of Armenian return converts to further the debates on Turkish secularism and to critique the body of scholarship that welcomes the governing Justice and Development Party's legal reforms as a measure of growing religious tolerance. In the article's first part I analyze the historical foundations of the regulation of religion and name changes in Turkey by fully and explicitly engaging with law as a site where minority difference is constructed, authorized, and challenged. The article's second half offers an alternative reading of how tolerance functions as an aspect of the Justice and Development Party's reforms. Based on my investigation of specific legal forms of argument that converted Armenians and their lawyers put forward in today's secular courts, and how legal officers of the state respond to them, I demonstrate that legal reform has shifted the definition of religion as a marker of minority difference in legal space. I argue that the historical context of name change and religious conversion forces the limits of existing understandings of freedom of religion in Turkey, and that this renders visible historical injustices that cannot be resolved simply through the notion of "religious tolerance" in the courts.
\end{abstract}

